I6 a 18 de outubro de 2019 - Campinas | Brasil

\title{
Dinâmicas atuais da urbanização na Região Metropolitana de Campinas e as disputas por cidadania territorial
}

\author{
Alice Peres dos Santos Neta*, Ana Carolina de Moraes Ricardo, Ana Luisa Chinchette, Julia Ferreira dos \\ Santos, Livia Carneiro Guimaraes, Rafaela Altenfelder Vernucci, Isadora Garcia, André Pasti
}

\section{Resumo}

A pesquisa busca analisar diversos aspectos do processo contemporâneo de urbanização da Região Metropolitana de Campinas (RMC), sobretudo as disputas pelo direito à cidade e pela cidadania territorial.

\section{Palavras-chave:}

Região Metropolitana de Campinas, planejamento urbano, cidadania territorial.

\section{Introdução}

A pesquisa buscou analisar aspectos das disputas por cidadania territorial nas dinâmicas atuais da urbanização da RMC. Com o empresariamento urbano e a urbanização corporativa (SANTOS, 2008; SÁNCHEZ, 2015) como lógicas predominantes, a luta por cidadania entra em contradição com práticas hegemônicas de planejamento.

\section{Resultados e Discussão}

A perspectiva dominante do planejamento das cidades acompanha a negação da lógica do cidade como um direito. O direito à cidade é um direito coletivo, que consiste não apenas na utilização de recursos urbanos, como também engloba processos sociais e a participação das decisões sobre o futuro da cidade (HARVEY, 2013). Esse direito é violado para grande parte da população da RMC. Foram investigadas diferentes manifestações desse processo e de disputas pela cidadania territorial.

Nos espaços de lazer, observa-se uma ressignificação de seus objetivos, com o fortalecimento de projetos que passam a colocar os espaços públicos livres cada vez mais a mercê do sistema de consumo que rege a vida contemporânea. Observa-se uma tendência de organizar os espaços públicos à imagem de shoppings centers (SERPA, 2007), valorizando o consumo como atividade de lazer. Por outro lado, observam-se conflitos pela criação e democratização de espaços públicos - como a luta da Maloca Arte e Cultura (Vila União, Campinas) para manter a área direcionada ao uso da comunidade do lugar.

As disputas em função da negação histórica da moradia como um direito impulsionaram movimentos sociais que utilizam a ocupação urbana como estratégia de luta construção de moradias em propriedades que não exercem sua função social, por pessoas que não possuem acesso ao mercado formal de moradia. A negação do direito à cidade pode ser observada também na utilização estratégica do planejamento para a remoção de agentes estigmatizados de áreas valorizadas - como no caso da criação do Jardim Itatinga, em Campinas nos anos 1960, para segregar atividades de prostituição (HELENE, 2012). A negação do direito à cidade se articula com violações ao direito à saúde. Nas ocupações urbanas, estigmatizadas no imaginário urbano dominante, a precariedade do acesso aos serviços de saúde se soma a enfermidades básicas relacionadas com a precariedade habitacional. A prevenção, papel da unidade básica de saúde, deveria ser o foco nesses casos. No Jardim Itatinga, também há um padrão de saúde, com enfoque apenas em campanhas de controle às Infecções Sexualmente Transmissíveis, reafirmando o estigma da prostituta como "mulher doente". Dentro da parcela da população que tem a sua cidadania negada, estão também as pessoas em situação de rua. Elas são vistas como barreiras ao "embelezamento" e à mercantilização da cidade. A chamada "arquitetura antiindesejáveis" - investigada na cidade de Paulínia - busca adaptar o espaço de forma efetiva aos consumidores por meio da expulsão dessa população (MELGAÇO, 2010).

Entre as desigualdades produzidas nessa urbanização, estão ainda as barreiras que limitam a acessibilidade das pessoas com deficiência. Se "morar na periferia é condenar-se duas vezes à pobreza" (SANTOS, 2002), ao morar na periferia e ser uma pessoa com deficiência, as pessoas estão triplamente "condenadas", graças as opções escassas e dificuldade de acesso ao transporte.

Para que o direito à cidade seja exercido integralmente, se faz necessário que seus cidadãos tenham a possibilidade de ter decisões ativas na cidade. Em Campinas, observase uma sub-representação das mulheres negras nos espaços de planejamento. As discriminações de gênero e raça operam de maneira conjunta na violação de direitos das mulheres negras (HIRATA, 2014) e se sobrepõem na construção do espaço urbano. Há um silenciamento dessas mulheres sobre as violações de direitos na cidade.

\section{Conclusão}

O planejamento tem sido um instrumento de criação e aprofundamento das desigualdades na cidade. É necessário reconhecer, por outro lado, diferentes aspectos da luta pelo direito à cidade, considerando todos e todas as pessoas na busca de sua identidade, recursos e valores - sujeitos corporificados (RIBEIRO, 2013) em luta pela cidadania territorial efetiva.

\section{Agradecimentos}

Ao CNPq, à equipe do PIBIC-EM e à Direção do Cotuca.

HARVEY, D. O direito à cidade. Piauí, n. 82, 2013.

HELENE, D. A cidade das meninas o Jardim Itatinga e o confinamento urbano da prostituição. Rio de Janeiro, 2012.

HIRATA, H. Gênero, classe e raça. Tempo Social, 26 (1), 2014.

MELGAÇO, L. A cidade e a negação do outro, 2010.

SÁNCHEZ, F. A reinvenção das cidades para um mercado mundial.

Chapecó: Argos, 2015.

SANTOS, M. O espaço do cidadão. São Paulo: Edusp, 2002.

SANTOS, M. A Urbanização Brasileira. São Paulo: Edusp, 2008.

RIBEIRO, Ana Clara Torres. Sujeito corporificado e bioética: caminhos da democracia. In: Por uma sociologia do presente. Letra Capital, 2013.

SERPA, A. O espaço público na cidade contemporânea. Contexto, 2018. 